\title{
Lipid index changes in the blood serum of patients with hyperplastic and early neoplastic lesions in the ovaries
}

Mikołaj Karmowski ${ }^{1 \dagger}$, Krzysztof A Sobiech $^{2+}$, Jacek Majda ${ }^{3+}$, Piotr Rubisz ${ }^{1 *+}$, Stanisław Han ${ }^{4 \dagger}$ and Andrzej Karmowski ${ }^{1+}$

\begin{abstract}
Background: The authors used the lipid index (WL) to monitor lipid changes before and after surgery. The surgical operation performed was the simultaneous enucleation of a cystic tumor of the hilum ovarii in its entirety (with diagnosis of a simple cyst or teratoma adultum) in groups of 20 patients.

Objectives: To compare the lipid index WL in the blood serum of patients undergoing surgery treatment at the following times: before and 7 days after surgery, and 6 and 12 months after surgery.

Material and methods: The research material was the blood serum of women aged about 24 years. The authors divided the patients into 3 groups: two groups of 20 women and a control group. The concentrations of the lipid parameters were measured and the lipid index WL was calculated.
\end{abstract}

Results: Statistically significant differences were found between the lipid index of serum from patients with diagnosed ovarian neoplasms and the index of serum from healthy subjects; differences were demonstrated in the postoperative period, particularly 6 and 12 months after surgery.

Conclusions: The lipid index WL proved useful in diagnosing ovarian neoplasm (simple cysts and teratoma adultum) and in monitoring the postoperative period.

Keywords: Lipid index, Ovarian neoplasm

\section{Background}

Since 2002, the lipid index has been successfully used in oncogynecological diagnostics. The index is calculated using the concentrations of HDL and LDL lipoprotein, apolipoprotein A1 and B, and triglycerides (TG) [1,2].

The usefulness of this marker has been demonstrated in monitoring changes in lipid metabolism in perimenopausal women undergoing gynecological surgery, as well as in the assessment of hormone replacement therapy [3-5].

Based on these results, it was decided that the objective of the present study would be to determine the diagnostic role of this indicator in the blood serum of

* Correspondence: piotr.rubisz@gmail.com

${ }^{\dagger}$ Equal contributors

${ }^{1}$ First Department of Gynecology and Obstetrics, Wrocław Medical University, Wrocław, Poland

Full list of author information is available at the end of the article women undergoing surgery due to neoplastic hyperplasia within the ovary and parovarian mesonephritic structures. These procedures were performed due to a diagnosis of teratoma: adultum teratoma [6-8] or a simple cyst [9-11].

The motivation to undertake this research lies in the fact that the authors have found no comprehensive publication in the available literature describing the lipid index in gynecological oncology.

\section{Material and methods}

The study included three groups of women, each of up to 20 people.

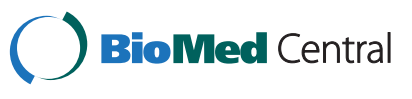

(c) 2014 Karmowski et al.; licensee BioMed Central Ltd. This is an Open Access article distributed under the terms of the Creative Commons Attribution License (http://creativecommons.org/licenses/by/4.0), which permits unrestricted use, distribution, and reproduction in any medium, provided the original work is properly credited. The Creative Commons Public Domain Dedication waiver (http://creativecommons.org/publicdomain/zero/1.0/) applies to the data made available in this article, unless otherwise stated. 
Group I contained healthy women with an average age of 24.3 years. The criteria for inclusion in Group I were as follows:

- no pathological findings in gynecological examination;

- normal values of urine analyses, blood counts, and diagnostic enzymology;

- age between 18 and 28 years; and

- BMI between 19.5 and $26 \mathrm{~kg} / \mathrm{m}^{2}$.

The exclusion criterion was a history of liver, kidney, or bile-duct disease.

Patients in Group II were operated on because of neoplastic lesions within the ovarian and parovarian structures (appendages). Histopathological examination showed benign hyperplasia of the simple cyst type was found. The following are the criteria for inclusion into the group:

- age between 18 and 28 years;

- tumor size between 5 and $22 \mathrm{~cm}$, as determined by means of gynecological examination and confirmed by ultrasound examination;

- histopathological diagnosis.

The patients in Group III were operated on because of neoplastic lesions within the appendages (ovary, paroophoron, epoophoron, or other mesonephritic structures). Postoperative histopathological examination revealed a mature teratoma. The indication for surgery in both Groups II and III was tumor size of 5-20 cm in diameter, determined by means of gynecological examination and confirmed by ultrasound examination.

The range of performed operations included enucleation of the cyst in one piece, preserving oncological asepsis and followed by intraoperative pathology consultation.

Biochemical measurements were performed prior to surgery (A), 7 days after surgery (B), and 6 and 12 months after surgery ( $C$ and $D$, respectively).

The research material was blood taken from the basilic vein. The samples obtained from blood serum were analyzed by assessing the concentration of:

- apolipoprotein A and B using immunoturbidimetric method with the Orion Diagnostica reagent on a Technicon RA 1000 (USA) analyzer;

- triglycerides (TG) using the enzymatic colorimetric method;

- lipoprotein HDL cholesterol by precipitation; and

- total cholesterol (TCH) using the enzymatic oxidase method.
The lipoprotein LDL cholesterol level was calculated using the Friedewald formula.

Given the lipid metabolism parameters, the lipid index $W L$ was calculated using the formula $[1,2]$ :

$$
W L=\frac{\left(H D L+\frac{T G}{6}\right) * \frac{A p o A 1}{30} * 10}{\left(L D L+\frac{T G}{5}\right) * \frac{A p o B}{20}}
$$

The obtained results are presented as arithmetic means and standard deviations, which were statistically analyzed using Student's $t$-test and adjusted with the Bonferroni correction, whose significance level for the studied index was $0.05 / 5=0.01$.

The study was performed and financed under grant No. 500/03 from Wrocław Medical University, Poland.

\section{Results}

Table 1 presents the data on the lipid index $W L$ in the blood serum from the test groups. The results of the statistical analysis are shown in Table 2. It is clear from the data that there was a statistically significant decrease in this parameter in both Groups II and III, compared to the control Group I $(\mathrm{p}<0.001)$. After surgery, Groups II and III showed the highest statistically significant differences between times A and D $(\mathrm{p}<0.001)$. Other results for these two groups between the different time points were highly significant $(\mathrm{p}<0.01$ and $\mathrm{p}<0.001)$, except for time points $\mathrm{A}$ and $\mathrm{B}$, that is, before and 7 days after surgery.

The relationship of the percentage of this parameter in both groups compared with the control group is presented in Figure 1. Before the surgery, both groups had lower lipid indices $W L$, at approximately $31 \%$ for Group II and 60\% for Group III. After the procedure, a constant upward trend was observed in this parameter, and the data at time D are about $52 \%$ for Group II and about $85 \%$ for Group III.

Table 1 Lipid index $W L$ in blood serum in the study groups

\begin{tabular}{lll}
\hline Group I & & $\begin{array}{l}\text { Lipid index WL } \\
\mathbf{9 . 9 9} \pm \mathbf{0 . 8 5}\end{array}$ \\
\hline Group II & A. Before surgery & $3.16 \pm 0.41$ \\
(simple cyst) & B. 7 days after surgery & $3.19 \pm 0.40$ \\
& C. 6 months after surgery & $4.41 \pm 0.60$ \\
& D. 12 months after surgery & $5.25 \pm 0.35$ \\
Group III & A. Before surgery & $5.94 \pm 0.44$ \\
(teratoma adultum) & B. 7 days after surgery & $5.98 \pm 0.48$ \\
& C. 6 months after surgery & $6.40 \pm 0.46$ \\
& D. 12 months after surgery & $8.51 \pm 0.69$ \\
\hline
\end{tabular}




\section{Table 2 Statistical analysis}

\begin{tabular}{|c|c|}
\hline Groups & $P$ value \\
\hline I: || A & 0.001 \\
\hline I: III A & 0.001 \\
\hline$\|\mathrm{A}:\| \mathrm{B}$ & NS \\
\hline$\|\mathrm{A}:\| \mathrm{C}$ & 0.001 \\
\hline$\|A:\|$ D & 0.001 \\
\hline$\|$ B: \|C & 0.001 \\
\hline$\|\mathrm{B}:\| \mathrm{D}$ & 0.001 \\
\hline$\|C:\| D$ & 0.001 \\
\hline III A: III B & NS \\
\hline$\||| A:\| \mid \| C$ & 0.01 \\
\hline III A: III D & 0.001 \\
\hline\|\| B: \|\|$C$ & 0.01 \\
\hline ||| B: III D & 0.001 \\
\hline\|\|$C: \| \mid$ & 0.001 \\
\hline
\end{tabular}

\section{Discussion}

Previous studies using the lipid index $W L$ have shown its usefulness in monitoring hormone replacement therapy in postmenopausal women.

In the search for useful diagnostic indicators in gynecological oncology, a slight deviation from the norm of lipid parameters was found. However, the application of the lipid index $W L$, which is calculated from HDL, LDL, TG, ApoA1, and ApoB, showed a decrease in this parameter of up to $30 \%$ in the serum of patients, as compared with healthy subjects. Further studies have shown differences that depend on the type of gynecological disease.

This information encouraged the authors to conduct further diagnostic tests and monitoring over the 12 months after the operations. Results that are particularly interesting include those for times C and D, where there was an increase in the lipid index $W L$, slowly reaching the values characteristic of healthy women of similar age and BMI. After one year, indices of growth of about $25 \%$ for teratoma adultum and about $20 \%$ for simple cysts was found, which correlates with the clinical evaluation of the patients.

It appears that further clinical trials on this indicator which also take into account data regarding physical activity, diet, and risk factors for diseases of civilization will allow for the development of a healthy control system based on the observation of lipid metabolism in women.

\section{Consent}

Written informed consent was obtained from the patient for the publication of this report and any accompanying images.

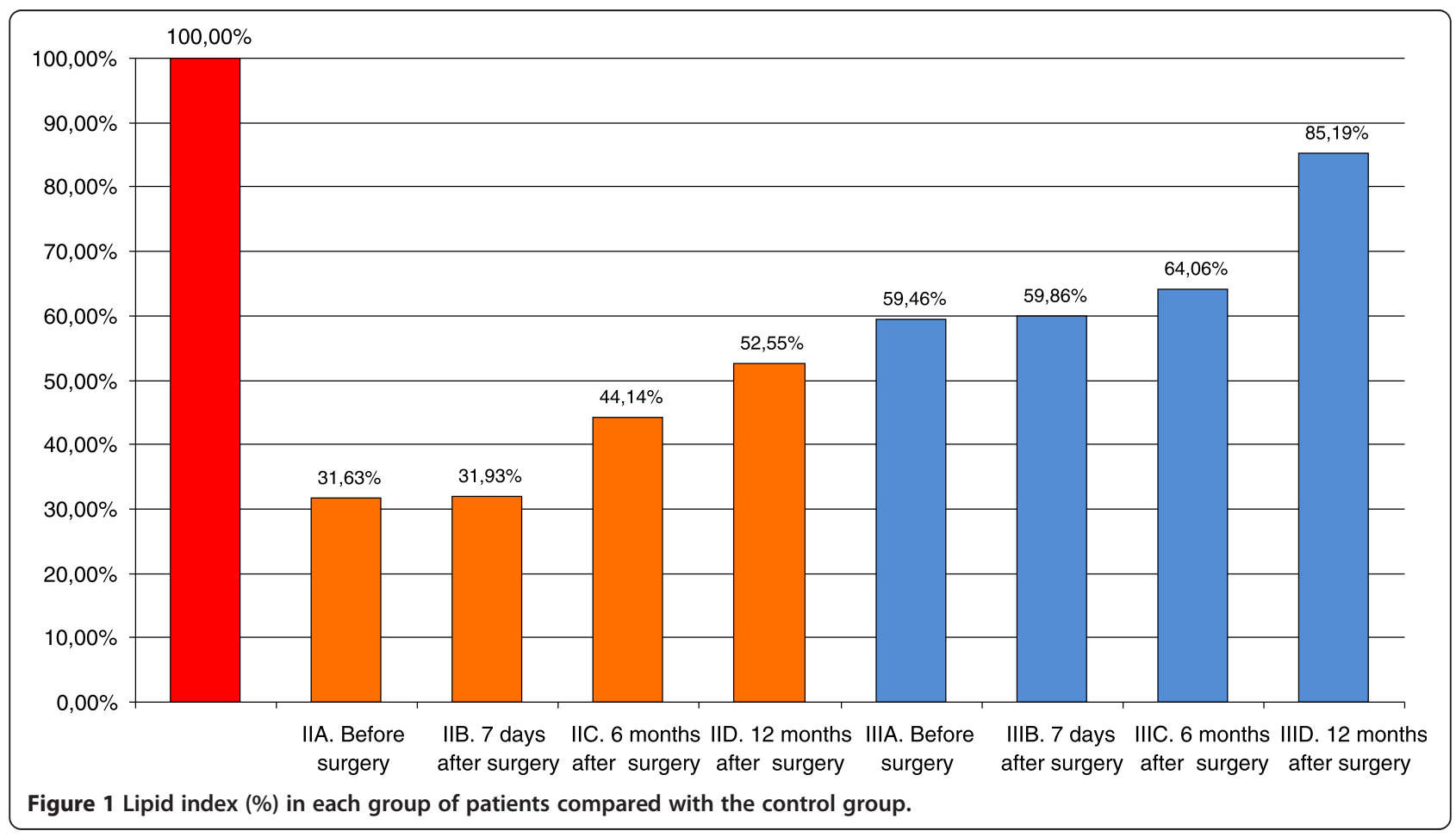




\section{Abbreviations}

BMI: Body mass index; HDL: High-density lipoprotein; LDL: Low-density lipoprotein; TG: Triglyceride.

\section{Competing interests}

The authors declare that they have no competing interests.

\section{Authors' contributions}

MK, KAS, JM, and PR are responsible for writing the manuscript, the conception, and the final design. MK, KAS, and AK collected and assembled the data and wrote the manuscript. PR and SH performed the statistical analysis. MK, KS and SH designed the study and critically revised the study for intellectual content. All authors read and approved the final manuscript.

\section{Author details}

${ }^{1}$ First Department of Gynecology and Obstetrics, Wrocław Medical University, Wrocław, Poland. ${ }^{2}$ Department of Human Biology, University School of Physical Education in Wrocław, Wrocław, Poland. ${ }^{3}$ Department of Laboratory Diagnostics, Fourth Military Hospital, Wrocław, Poland. ${ }^{4}$ Hasco-Lek

Pharmaceutical Production Company S.A., Wrocław, Poland.

Received: 23 July 2014 Accepted: 21 September 2014

Published online: 27 September 2014

\section{References}

1. Wochyński Z, Sobiech KA, Majda J: The assessment of adaptation to physical exercise in soldiers with the use of the lipid index as the qualifying factor for physical fitness tests. Lek Wojsk 2001, 77:218-221 [in Polish].

2. Wochyński Z, Sobiech KA, Majda J: Lipid index in the evaluation of physical capacity. Nowiny Lek 2005, 74:39-44 [in Polish].

3. Andrzej K, Sobiech KA, Małgorzata P, Halina M, Mikołaj K, Marta G-B, Dorota $J$ : The activity of Arylsulfatase $A$ in patients with benign ovarian tumors. Internet J. Gynecol. Obstet 2007, 6:2.

4. Karmowski A, Sobiech KA, Majda J, Karmowski M, Markuszewski M, Kwietniak G, Kotarski A, Kotarska E, Wronecki K: The value of lipid index in the blood serum of perimenopausal women undergoing gynecological surgery. Gin Pol 2004, 75:847-851 [in Polish].

5. Karmowski A, Sobiech KA, Markuszewski M, Majda J, Łątkowski K, Karmowski $\mathrm{M}$, Balcerek M, Kotarska E: Values of the lipid indexes in monitoring of the hormone replacement therapy in the postmenopausal women. Adv Clin Ex Med 2005, 14:725-729 [in Polish].

6. Bal J, Gabryś MS, Jałocha L: Selected cell molecular pathways in the pathogenesis of ovarian teratomas. Post Hig Med Dośw 2009, 63:242-249 [in Polish].

7. Dahl N, Gustavson KH, Rune C, Gustavsson I, Pettersson U: Benign ovarian teratomas: an analysis of their cellular origin. Cancer Genet Cytogenet 1990, 46:115-23.

8. Gilks CB: Subclassification of ovarian surface epithelial tumors based on correlation of histologic and molecular pathologic data. Int I Gynecol Pathol 2004, 23:200-205.

9. Acs G: Serous and mucinous borderline (low malignant potential) tumors of the ovary. M I Clin Pathol 2005, 123:S13-57.

10. Funt SA, Hricak H: Ovarian malignancies. Top Magn Reson Imaging 2003, 14:329-337.

11. Hart WR: Mucinous tumors of the ovary: a review. Int J Gynecol Pathol 2005, 24:4-25.

doi:10.1186/s13048-014-0090-6

Cite this article as: Karmowski et al: Lipid index changes in the blood serum of patients with hyperplastic and early neoplastic lesions in the ovaries. Journal of Ovarian Research 2014 7:90.

\section{Submit your next manuscript to BioMed Central and take full advantage of:}

- Convenient online submission

- Thorough peer review

- No space constraints or color figure charges

- Immediate publication on acceptance

- Inclusion in PubMed, CAS, Scopus and Google Scholar

- Research which is freely available for redistribution

Submit your manuscript at www.biomedcentral.com/submit 